российских дореволюционных авторов, мы полагаем, что А. Юнг был оригинальным выразителем того направления экономической мысли, которое обосновывало интересы земельных собственников и связанных с ними крупных фермеров. Именно это и обусловило эволюцию его отношения к событиям французской революции.

$$
* * *
$$

1. Кареев, Н.И. Крестьяне и крестьянский вопрос во Франции в последней четверти XVIII века/ Н. И. Кареев Москва: Тип. М. Н. Лаврова и Ко, и А. И. Мамонтова, 1879. — 491 с.

2. Киселева, О.А. Общественно-политическая мысль Просвещения (конец XVII - XVIII в.) / Учебное пособие для студентов исторического факультета. 2-е изд., / О. А. Киселева Вологда: изд-во ВГПУ, 2012.- $175 \mathrm{c}$

3. Киселева, О.А. О содержании и целях преподавания истории в педагогических вузах // Реформа системы высшего образования в сфере гуманитарных и социальных наук: проблемы и перспективы США и Россия. Материалы международной конференции, СПб., 15 -17 мая 2006г.-/О. А. Киселева Санкт-Петербург: Изд-во РГПУ им. А.И. Герцена, 2006. -243 с. С. 91 - 94.

4. Лавровский, В.М. Исследование по аграрной история Англии XVIII-XIX вв./ В.М. Лавровский Москва: Наука, 1966. - С.248

5. Люблинская, А. Д. Французские крестьяне в XVI - XVIII вв. / А. Д. Люблинская Ленинград: Наука $1978-154 \mathrm{c}$.

6. Токвиль, А. Старый порядок и революция / А. Токвиль ; пер. с фр. Л. Н. Ефимова. - СПб. : Алетейя, 2008. - $248 \mathrm{c}$.

7. Юнг, А. Путешествия по Франции 1787, 1788 и 1789./ А. Юнг Пер. с англ. и примечания С.Н. Искюля и Д.В.Соловьева. Санкт-Петербург: ИНАПРЕСС, 1996 . - 431 с.

\title{
Щукина У.О. \\ Характерные черты пожалований французскому имперскому дворянству на начальных этапах его формирования (1804 - 1814)
}

Вологодский государственный университет

(Россия, Вологда)

doi: $10.18411 / l j-31-10-2017-40$

idsp: 000001:lj-31-10-2017-40

\section{Аннотация}

Исследование знакомит с принципами, лежавшими в основе процесса формирования привилегированного слоя общества в период Первой Империи во Франции. Отражены особенности восстановления и жалования титулованным особам майоратов.

Ключевые слова: майораты, Наполеон Бонапарт, Первая Империя, принципы формирования имперского дворянства.

\section{Abstract}

The study introduces the principles that lying the process of forming a privileged segment of society during the first empire in France. The features of reconstruction and salaries of titledperson Entail estates are reflected.

Keywords: entailed estates, First Empire Napoleon Bonaparte, principles of the formation of imperial nobility.

Интерес к изучению различных аспектов истории революционного времени и наполеоновской эпохи во Франции $(1789$ - 1814) не угасает по настоящее время [3, с. 117 120]. Отечественная и зарубежная историография богата множеством общих работ (труды Н. И. Кареева, Е. В. Тарле, А. З. Манфреда, А. Тьера, Ф. Кирхейзена и др.) и исследований специальных вопросов (работы Д. М. Туган-Барановского, А. Ю. Иванова, Ф. Масона и др.). 
Обозначив одной из главных задач данной статьи изучение принципов, на которых основывался процесс формирования (предмет исследования) нового имперского дворянства (объект) в период Империи (1804 - 1814), мы привлекли к работе различные виды источников, включая законодательные акты (Гражданский Кодекс 1804 г., сенатусконсульты) и источники личного происхождения (мемуары графини К. де Ремюза, воспоминания Наполеона Бонапарта, записанные Лас Казом). Их анализ и обращение к научной литературе позволяет всесторонне рассмотреть избранную тему.

Став императором Франции, Наполеон I счел необходимым учредить институт имперского дворянства по многим причинам, в том числе с целью укрепления власти. Сенатус-консульт от 18 мая 1804 г. и декрет от 1 марта 1808 г. юридически оформили создание привилегированного слоя общества. Вводились пожизненные звания Великих сановников и офицеров Империи [7], восстанавливались титулы герцога, графа, барона и шевалье.

В основу процесса формирования имперского дворянства легли взаимосвязанные между собой принципы, которые усложняли практику жалования титулов и привилегий, ограничивали список лиц, возводимых в имперское дворянство. Перекрывая путь небогатым слоям населения к получению титулов, созданный порядок подчеркивал элитарность нового института. Прежде всего отметим отсутствие возможности куплипродажи дворянских титулов: они могли быть пожалованы военным или государственным служащим, деятелям искусств по личному распоряжению Наполеона I. Помимо этого, дворянские титулы носили наследственный статус.

Расценивая дворянство как опору своего режима, Наполеон I стремился упрочить положение привилегированных особ в стране и обеспечить им устойчивое финансовое положение. Сенатус-консульт от 14 августа 1806 г. восстановил учреждение майоратов земельных владений, на которые распространялось право наследования по принципу первородства - старшему сыну. Майораты взимались с оккупированных или аннексированных Францией территорий $[8$, с. 255] и приносили определенный доход их держателям [4, с. 265-266]. Майорат не мог обмениваться на денежный эквивалент, закладываться за долги, продаваться с аукциона, но он подлежал обязательному налогообложению. В Гражданском кодексе (1804 г.) встречаем поправку к 896 статье, отсылавшую к сенатус-консульту от 14 марта 1806 г.: «...свободные имущества, составляющие достояние наследственного титула... могут быть передаваемы по наследству» (старшему сыну в законном браке) [1], что говорит о взаимосвязи принципов наследственности титулов и закрепления за ними источников дохода.

Процессы жалования дворянских титулов и учреждения майоратов позволяют проследить некоторые характерные черты политики лавирования, свойственной бонапартистскому режиму.

Хорошо известно, что для Франции конца XVIII - начала XIX вв. была характерна частая смена форм правлений, начало которой было положено в период Великой французской революции XVIII в.: конституционная монархия (1789 - 1792), Первая республика (1792 - 1794), Директория (1795 - 1799), Консульство (1799 - 1804) и Первая Империя (1804 - 1814) [2, с. 40]. Возрождение Наполеоном Бонапартом монархической формы правления сделало неизбежным формирование нового института дворянства [8, с. 254-255]. Императорская власть нуждалась в безоговорочной поддержке и со стороны титулованных ранее особ. Но старая аристократия (приверженцы династии Бурбонов), получив новые имперские титулы, стремилась восстановить свои прежние права [6, т. 3, с. 250-251], обрести устойчивое положение при дворе Наполеона I. В свою очередь, принципиальное отличие нового дворянства, его известная «демократичность» выражалась в революционном девизе: «карьера, открытая талантам». Это воспринималось как возможность для многих офицеров, государственных служащих, деятелей искусств получить привилегии и соответствующий титул. 
Нередко титулованные особы получали поощрения в виде денежных дотаций $[8, \mathrm{c}$. 255]. Поводом к этому послужило стремление Наполеона I укрепить служебное рвение подданных, развить соревновательный дух в желании получить дворянский титул. Но следует заметить, что более высокие премии определялись для лиц, находившихся на военной службе, при этом учитывались чин и род войск, в которых служил дворянин, а также удачный исход военных кампаний или сражений. Очевидно, что император выступал сторонником дарования титулов и привилегий в качестве поощрения, достойного вознаграждения стремлений достигнуть «совершенства в своем ремесле» $[5, \mathrm{c}$. 129].

Таким образом, формирование имперского дворянства изначально преследовало цель укрепить социальную базу наполеоновского режима и было одним из проявлений специфической бонапартистской социально-политической тактики.

$$
* * *
$$

1. Гражданский кодекс (Кодекс Наполеона) 1804 г. [URL: https://www.ipsub2.udsu.ru]

2. Киселева, О. А. Политическое развитие ведущих стран Запада в новое время: от абсолютизма к буржуазному конституционализму / О. А. Киселева. - Вологда: ВГПУ, 2010. - 112 с.

3. Киселева, О. А. Социальные революции Нового времени: проблемы изучения в высшей школе // Проблемы фундаментальной подготовки в школе и в вузе в контексте современности. Межвузовский сборник научных работ. Выпуск 7 / Ред.-сост. А. Е. Новиков. - Череповец: ЧГУ, 2017. - 324 с.

4. Коркунов, Н. М.Сословное деление на Западе / Н. М. Коркунов // Русское государственное права / Н. М. Коркунов. - Санкт-Петербург: Типография М. М. Стасюлевича, 1899. - 573 с.

5. Максимы и мысли узника Святой Елены. Рукопись, найденная в бумагах Лас Каза. Перевод с английского / [Пер.: С. Н. Искюль]. - Санкт-Петербург: Азбука, 2000. - 215 с.

6. Ремюза, К. де. Мемуары г-жи де Ремюза $(1802$ - 1808 гг.): в 3 т. / К. де Ремюза. - Москва: Книгоиздательство К. Ф. Некрасова, 1912 - 1915. - Т. 3. - 306 с.

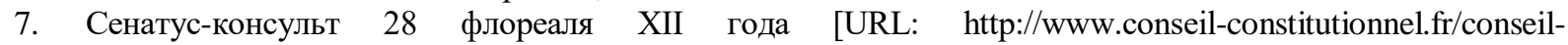
constitutionnel/francais/la-constitution/les-constitutions-de-la-france/constitution-de-l-an-xii-empire-28-florealan-xii.5090.html]

8. Тюлар, Ж. Наполеон, или Миф о «спасителе» / Ж. Тюлар. - Москва: Молодая гвардия, 2009. - 362 c. 